\title{
THIRD ANNUAL LIST OF PUBLISHED PAPERS
}

READ BEFORE THE NEW YORK MATHEMATICAL SOCIETY, TOGETHER WITH THE PLACES OF THEIR PUBLICATION.

Craig, J. E. Negative-Reciprocal Equations. Read June 3, 1893. Proceedings of the United States Naval Institute, vol. 19, No. 2, pp. 201-212, 1893.

Craig, Thomas. Note on Monogenic Functions of a Single Variable. Read Oct. 7, 1893. Bulletin of the New York Mathematical Society, vol. 3, No. 3, pp. 78-79, Dec., 1893.

DURel, Fletcher. Application of the New Education to the Differential and Integral Calculus. Read Nov. 4, 1893 . The American Mathematical Monthly, vol. 1, No. 1, pp. 15-19, Jan., No. 2, pp. 37-41, Feb., 1894.

Eсноц, W. H. Note on the Theory of Functions. Read Oct. \%, 1893. Annals of Mathematics, vol. 8, No. 2, pp. 45-51, Jan., 1894.

Engler, Edmund A. Geometrical Constructions for Cutting from a Cone of Revolution Plane Sections $(a)$ of given eccentricity, $(b)$ of given latus rectum. Read May 6, 1893. Transactions of the Academy of Science of St. Louis, vol. 6, No. 8, pp. 183-190, May, 1893.

Johnson, W. Woorser. Gravitation and Absolute Units of Force. Read April 7, 1894. Bulletin of the New York Mathematical Society, vol. 3, No. 8, pp. 197-199, May, 1894.

Martin, Artemas. On Powers of Numbers whose Sum is the Same Power of Some Number. Read Oct. 3, 1891. Quarterly Journal of Pure and Applied Mathematics, vol. 26, No. 3, pp. 225-227, May, 1893.

Newcomb, Srmon. Modern Mathematical Thought. Read Dec. 28, 1893. Bulletin of the New York Mathematical Society, vol. 3, No. 4, pp. 95-107, Jan., 1894.

SAFFoRD, T. H. Instruction in Mathematics, as affected by Modern Algebraic and Geometrical Developments and by the Progress of the Physical Sciences. Read April 1, 1893. Bulletin of the New York Mathematical Society, vol. 3, No. 1, pp. 4-8, Oct., 1893.

Taber, Henry. On Orthogonal Substitutions. Read June 2, 1894. Bulletin of the Nero York Mathematical Society, vol. 3, No. 10, pp. 251-259, July, 1894. 